\title{
NAPELEMES HATÓTÁV NÖVELŐ KIEGÉSZÍTŐ RENDSZER FEJLESZTÉSE
}

\section{RANGE EXTENSION WITH SOLAR PANEL}

\author{
Tóth Tibor
}

Óbudai Egyetem, Bánki Donát Gépész és Biztonságtechnikai Mérnöki Kar, 1081, Magyarország, Budapest, Népszínház utca 8.; tothtibi100@gmail.com

\begin{abstract}
During my research, I found a solution to the problem that could help the spread of electric vehicles, promote their development, and promote renewable energy sources. The purpose of my research is to eliminate the disadvantages of electric vehicles, such as self-discharge, stationary charging and low range. I was thinking mainly of a solar-powered solution, because the small solar cells that are used in the Nissan Leaf type electric vehicle were solved to solve similar problems, but they bring very little or no positive returns to the car. With this upgrading, I've been designed such a larger and more useful solar powered auxiliary system for the electric car.
\end{abstract}

Keywords: solar panel, range extension, electric car.

\section{Összefoglalás}

Kutatásom során, olyan problémára kerestem a megoldást, amely segítséget nyújthat az elektromos járművek elterjedésének, elősegítheti azok fejlesztését, továbbá a megújuló energiaforrásokat is előtérbe helyezheti. Kutatásom célja, továbbá az elektromos járművek hátrányait próbálja kiküszöbölni, mint például az önkisülés, helyhez kötött töltés, illetve a kis hatótáv. Föként napelemes megoldáson gondolkoztam, mivel a hasonló problémák megoldására, a már forgalmazott Nissan Leaf típusú elektromos jármüvön alkalmazott kis napelemes cellák kínáltak megoldást, azonban ezek nagyon csekély vagy semmilyen pozitív hozamot nem hoztak az autó számára. Ennek a továbbfejlesztésén felbuzdulva terveztem meg, a nagyobb és hasznosabb napelemes hatótáv növelő kiegészítő rendszert.

Kulcsszavak: napelem, hatótáv növelés, elektromos autó.

\section{Kutatás eszközei és módszertana}

Az elektromos jármüvek energiaigénye igen magas, ezért az alternatív töltési rendszer kiépítéséhez a széleskörüen használható napenergiát vettem számításba, mivel Magyarországon, nagyjából 1kW/nm2 a felhasználható energia besugárzás, ezért a napelemes témában szereztem először ismeretet, majd az elektromos jármúvek felépítését és müködését vizsgáltam. A kutatás alapja az energiahozamra alapult, amit egy nemrégiben, a családi házunkra telepített napelemes rendszer modellezett. Mivel ez az otthoni rendszer $4 \mathrm{~kW}$ - teljesítményü, és 14 Napelem panelt tartalmaz, a modellezett jármü tetejére pedig 1 napelem panel fér, ezért az 1 panelre megfeleltetett teljesítményt vettem alapul, és ezeket figyelembe véve, végeztem és hasonlítottam össze a Budapesti körülményeket, a modellezett Nissan Leaf 30 kWh típusú elektromos jármüvön. A kapott eredményt összehasonlítottam a napelemes rendszerek telepítésnél használt energiahozam adatbázisával. Ennek eredménye lett egy elméletben müködő, 
illetve gyakorlati mérések alapján is létesíthetö, univerzálisan illeszthető töltőrendszer, az elektromos jármüvekhez, ami nem csak parkoláskor, de menet közben is tölti az elektromos hajtással rendelkező jármüvet. A modellezéshez egy komplett, a Nissan Leaf $30 \mathrm{kWh}$ modellhez illeszthetö rendszert terveztem, ami a mérések és a számítások alapján, átlagban 5,7 kilométert képes hozzáadni, a napi hatótávhoz. A tervezés során az LG neon2- $375 \mathrm{~W}$-os napelemet, illetve a hozzá kompatibilis IQ6 plusz inverter, és BSR konvertert választottam. Ennek a 3 fö komponensnek a paraméterei határozták meg a rendszer hozamát.

A kutatás sikerességét, és bizonyítását elösegítette a nemrégiben piacra hozott, hasonló megoldással megoldott Toyota Prius Plug in hibrid modelljében alkalmazott rendszer.

\section{Kutatás során felmerült prob- lémák, ezek megoldása}

A kutatás során megoldást kellett találnom a rendszer illesztésére, ezért olyan rendszert fejlesztettem, ami 3 fö komponensből áll, és garanciavesztés nélkül illeszthető az elektromos jármühöz a meglévő csatlakozási pontok felhasználásával. Meg kellett oldanom a biztonsági kivitelezést, amelyhez megfelelő érintésvédelmi és minőségi alkatrészeket használtam, illetve a könnyü szerelhetőséget, ami az univerzális használatot segítette, továbbá olyan beszállítókat keresni, amelyek megbízhatók, és jó ár-értékarányú terméket kínálnak. Ennek függvényében kijelenthetö, hogy körülbelül egy ilyen rendszer, 220 ezer forintból kihozható, és sok azonos méretű elektromos autóhoz illeszthető. Mivel a lítium-ion akkumulátor töltése csak 10\%-80\% között konstans, ezért a számított értékek ez az intervallum között valós, de mivel a városi elektromos jármüveket úgy is ebben a tartományban használjuk, ezért az egész számítás csak a két érték között valós.
Mivel napenergiából nyeri a rendszer a plusz töltést, ezért az árnyékos időszakokra is kellett gondolom, erre feszültség figyelést alkalmaztam, ez a vezetőnek pontos információval szolgál, hogy a rendszer mikor produktív, és hogy melyik töltési módszert érdemes alkalmazni (parkolás, vagy menet közbeni töltés).

Meg kellett oldani az érintésvédelmet, illetve az áramütés elkerülését. Ezekre Fi vagy más néven érintésvédelmi relét alkalmaztam, hogy az életveszélyes áramütést elkerüljük. Ezek a relék hamar beavatkoznak, és a rendszerünk épp marad, ami a költséghatékonyság miatt fontos. [1]

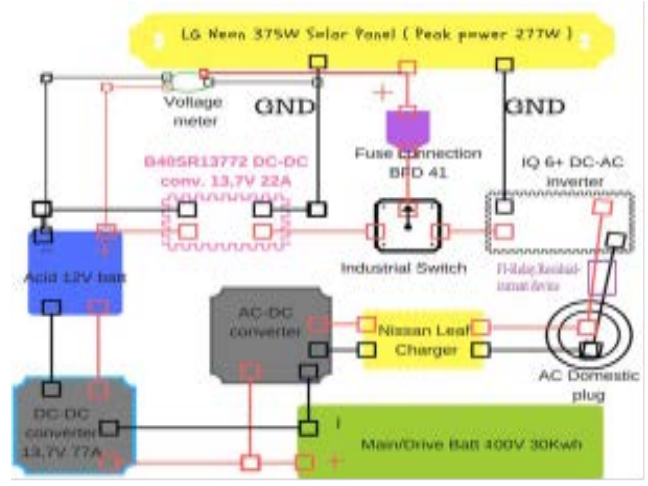

1. ábra. Tervezett rendszer blokkvázlata [1]

\section{A kutatás eredményei, különös tekintettel azok gyakorlati és társadalmi alkalmazhatóságára}

A rendszer 2 féle üzemmóddal rendelkezik: 1-es állásban, ha a kapcsolót elforgatjuk, akkor a menet közbeni töltést aktiváljuk, így a 12V-os rendszereket támogató savas akkumulátort tölthetjük, így spórolva a felhasznált energiával és kímélve a fö 30 kW-os akkumulátort, növelhetjük a hatótávot.

2-es állásban, a fő 30kW-os akkumulátort töltjük, viszont csak parkoló üzemmódban érhető el, amikor az autó áll, és $16 \mathrm{~V}$ fölé megy a napelem által megtermelt feszültég. 
A veszteségeket, illetve a Budapesti körülményeket figyelembe véve, illetve a Nissan Leaf 13 kWh-ás fogyasztásával kalkulálva kimondható, hogy a rendszer az alábbi energiahozamokat produkálja havi bontásban [2]:

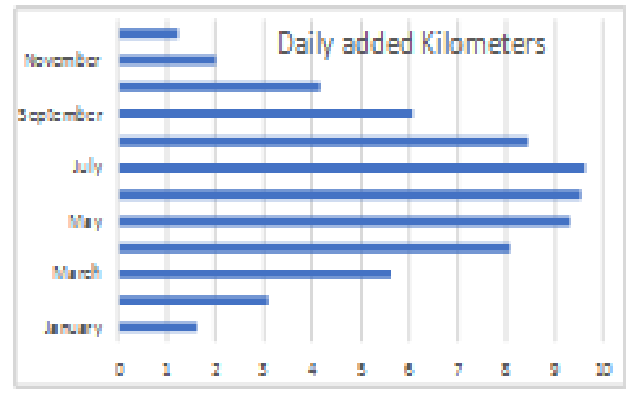

2. ábra. Napi éves kilométer hozzáadása a rendszernek

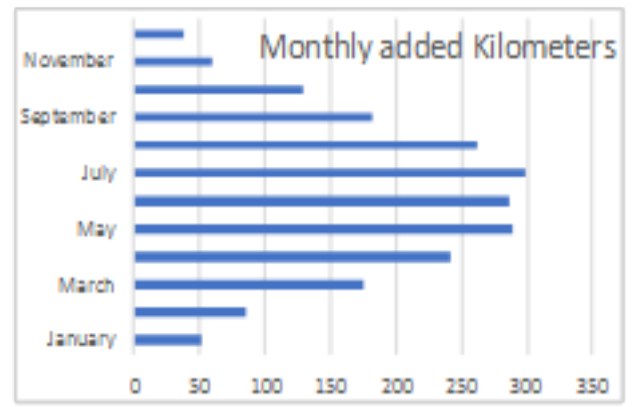

3. ábra. Havi éves kilométer hozzáadása a rendszernek

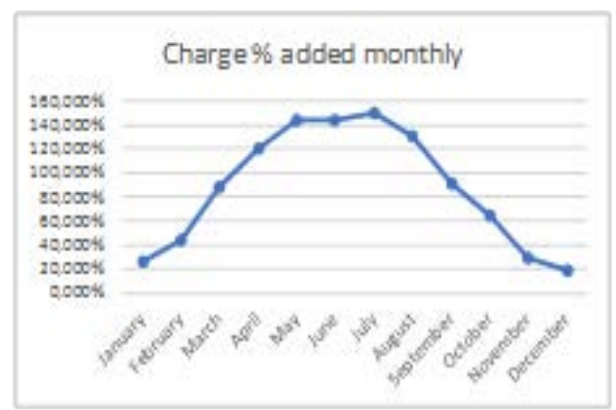

4. ábra. Akkumulátor kapacitásának havi százalék hozzáadása

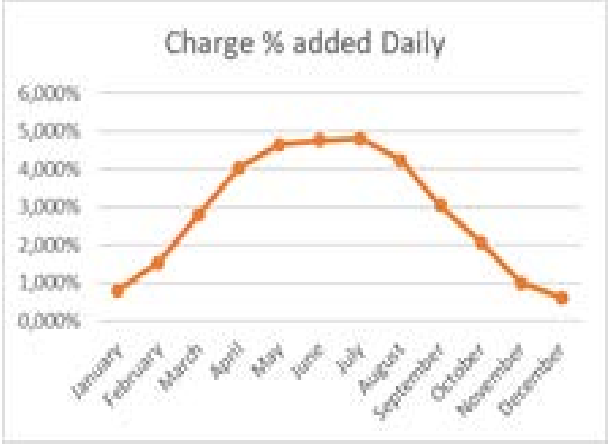

5. ábra. Akkumulátor kapacitásának napi százalék hozzáadása

A fenti eredmények születtek a tervezett univerzális napelemes töltörendszerre, így elmondható, hogy a használt technológiával, körülbelül a fenti adatokkal tudja bővíteni a hatótávot. Az éves megtermelt elektromos áram díja 11 ezer forint. A hasonló megoldással ellátott Toyota Plugin Hibrid modellben alkalmazott Panasonic Napelemes rendszer, egy $180 \mathrm{~W}$-os napelemet használ, ami sokkal kevesebb energiát képes termelni. Az általam tervezett rendszer produktívabb, olcsóbb és szélesebb körben alkalmazható.

\section{Továbbfejlesztési lehetőségek, tervek}

A fejlesztést a továbbiakban a jobb Inverter, illetve a magasabb hatásfokú napelem panel jelenti, amellyel még nagyobb hozamot lehet elérni, illetve a napelem panelek bővítésével a rendszer produktivitása növelhető. Az üzemmódok közötti kapcsolást egy elektromos komporátor áramkörrel lehetne helyettesíteni, így automatizálva és optimalizálva az automatikus müködést. Célszerü lenne tesztelni az adott rendszert a gyakorlatban, de ezt a finanszírozás hiánya miatt nem tudtam megtenni.

A számítógépes szimuláció, mivel napelemről beszélünk, csak hozzávetőleges eredménnyel szolgálna, ezért mivel az adatbázis elég pontos, könnyen ki tudtam szá- 
molni az adott feltételeknek megfelelö hozamot. A költségek optimalizálásához, más beszállítók termékei után is lehet nézni.

\section{Szakirodalmi hivatkozások}

[1] Panasonic looking to boost EV range with solar cells on car roofs, Photograph courtesy of Panasonic

https://www.autovistagroup.com/news-andinsights/panasonic-looking-boost-ev-rangesolar-cells-car-roofs (2017.06.26.)

[2] Panasonic's Photovoltaic Module HIT ${ }^{\mathrm{TM}}$ adopted for Toyota Motor's New Prius PHV Press Release, Panasonic Corporation http://news.panasonic.com/global/press/data/201 7/02/en170228-3/en170228-3.html (2017.02.28.)
[3] Katona M.: Toyota Prius 1.8 Plug-in Hybrid Executive teszt,

https://www.autonavigator.hu/cikkek/nincsmellebeszeles-08-l100-km-a-tesztfogyasztas/ (2017.09.18.)

[4] BU-409: Charging Lithium-ion Isidor Buchmann, Battery University http://batteryuniversity.com/learn/article/cha rging_lithium_ion_batteries (2017.05.09.)

[5] J. Huetter: New wrinkle for roof repairs: Panasonic photovoltaic roof for plug-in Toyota Prius

http://www.repairerdrivennews.com/2017/03 /28/panasonic-photovoltaic-roof/ (2017.03.28.)

[6] Véghely T.: Napelemes rendszerek villamos berendezései, Cser Kiadó, 2014 